\title{
Allogeneic stem cell transplantation after fludarabine, melphalan and thymoglobulin followed by early withdrawal of prophylactic immunosuppression in patients with acute lymphoblastic leukemia - update of single center study
}

\author{
L. RAIDA ${ }^{1, *}$, A. KUBA ${ }^{1}$, Z. RUSINAKOVA ${ }^{1}$, R. SZOTKOWSKA ${ }^{1}$, I. SKOUMALOVA ${ }^{1}$, E. FABER ${ }^{1}$, T. SZOTKOWSKI ${ }^{1}$, P. ROHON ${ }^{1}$, J. HUBACEK ${ }^{1}$, \\ K. INDRAK ${ }^{1}$, Z. PIKALOVA ${ }^{1}$, M. JAROSOVA ${ }^{1}$, M. DIVOKA ${ }^{1}$, K. LANGOVA ${ }^{2}$, T. PAPAJIK ${ }^{1}$
}

${ }^{1}$ Department of Hemato-Oncology, University Hospital and Faculty of Medicine and Dentistry, Palacky University, Olomouc, ${ }^{2}$ Department of Biophysics, Faculty of Medicine and Dentistry, Palacky University, Olomouc, Czech Republic

*Correspondence: raidal@volny.cz

Received November 30, 2016 / Accepted February 14, 2017

\begin{abstract}
Presented are updated results of allogeneic hematopoietic stem cell transplantations (HSCTs) in 25 adult patients with acute lymphoblastic leukemia (ALL) in complete remission (CR) after a reduced intensity conditioning (RIC) combining fludarabine $\left(150 \mathrm{mg} / \mathrm{m}^{2}\right)$ and melphalan $\left(140 \mathrm{mg} / \mathrm{m}^{2}\right)$ with thymoglobulin $(4.5 \mathrm{mg} / \mathrm{kg}$ or recently $4.0 \mathrm{mg} / \mathrm{kg})$ followed by early initiation of reduction and withdrawal of prophylactic posttransplant immunosuppression. The median post-transplant follow-up was 32 (range, 4-87) months. Stable engraftment of donor's hematopoiesis was achieved in all patients. Acute graft versus host disease (GVHD) as well as the chronic one were equally observed in four cases (16\%). Five patients (20\%) relapsed with ALL in the median of 9 (range, 3-15) months after HSCT. During the above post-transplant follow-up, 4 recipients (16\%) died. Disease progression and posttransplant complications were the cause of death in three (12\%) and one (4\%) of them, respectively. The probabilities of 2-year event-free (EFS) and overall survival (OS) were 70.3\% (95\% CI 51.9-88.7\%) and 86.1\% (95\% CI 71.6-100\%), respectively. Presented study confirmed our previously reported promising results and this approach may be considered as an alternative to traditional HSCTs performed in high-risk patients with ALL.
\end{abstract}

Key words: acute lymphoblastic leukemia, allogeneic hematopoietic stem cell transplantation, fludarabine, melphalan, thymoglobulin, graft-versus-host disease prophylaxis

Allogeneic HSCT still remains an important treatment modality in patients with ALL [1-3]. Transplantations after standard myeloablative conditionings may reduce the risk of post-transplant relapse but significant regimen-related toxicity (RRT) and non-relapse mortality (NRM) also negatively influence the outcome of patients. The lower cytoreductive potential of less toxic RICs results in insufficient suppression of leukemic clone [4]. Therefore standard approaches with post-transplant immunosuppressive prevention of GVHD (withdrawal is usually initiated aproximately on day +100 with the stop two or three months later) should not be used after reduced intensity HSCTs. Graft-versus-leukemia (GVL) reaction should be augmented as early as possible to achieve an immunological control of ALL and to avoid its recurrence after transplantation with RIC.

We previously reported the pilot results achieved on the small cohort of 13 patients with high-risk ALL in the first
CR allografted after RIC regimen combining fludarabine $\left(150 \mathrm{mg} / \mathrm{m}^{2}\right)$, melphalan $\left(140 \mathrm{mg} / \mathrm{m}^{2}\right)$ and "in vivo" T-cell depletion with antithymocyte globulin (ATG; thymoglobulin) at a total dose of $4.5 \mathrm{mg} / \mathrm{kg}$ [5]. Any "in vivo" T-depletion (including alemtuzumab) reducing the risk of GVHD, potentially triggered by melphalan associated gastrointestinal regimen related toxicity (RRT) [6-8], was prospectively compensated by the early withdrawal of prophylactic immunosuppression to maintain GVL effect. Promissing results with two observed relapses and no death were obtained in that pilot study during the follow-up median of 23 (range, 10-65) months. The probability of disease-free survival (DFS) was $76.9 \%$ (95\% CI 51-100\%). Thus, we decided to present an update of our experience with previously published approach to the patients undergoing allogeneic HSCT for ALL in the first or subsequent CR. 


\section{Patients and methods}

Patients and pre-transplant treatment. Presented study assessed the data of 25 adults with a median age at diagnosis of 34 (range, 20-58) years and available for a post-transplant follow-up of at least 3 months. Allogeneic HSCT was indicated for primary ALL in the first and second CR in 21 (84\%) and 2 patients (8\%), respectively. Two recipients $(8 \%)$ were allografted for lymphoblastic transformation of chronic myeloid leukemia (CML). Their induction therapy was identical to the approach in primary Philadelphia chromosome positive $(\mathrm{Ph}+)$ ALL. Therefore they were also included in this update. Both patients achieved molecular remission of the disease after induction chemotherapy in combination with the tyrosine kinase inhibitors (TKIs). Standard induction or consolidation chemotherapy was administered in accordance with the Cancer and Leukemia Group B (CALGB) 8811 or German Multicenter Study Group for Adult ALL (GMALL) 07/2003 protocols $[9,10]$. In $\mathrm{Ph}+\mathrm{ALL}$ patients, TKIs were added to their standard treatment. The characteristics of updated and enlarged study group including prognostic parameters and treatment protocols are highlighted and demonstrated in detail in Table 1 and Suppl Table 1, respectively.

The median time interval from diagnosis to HSCT was 6 months (range, 4-35 months). 17 patients (68\%) in the first CR receiving transplantation from unrelated donors underwent two chemotherapy cycles in addition to successful induction therapy according to the primary protocol. Six recipients (24\%) with available related donor were treated with only one consolidation therapy cycle before allografting. Except two specific cases, there was no significant difference in the interval from diagnosis to HSCT as in two patients subsequently transplanted from related available donors, consolidation chemotherapy had to be postponed due to serious infectious complications during induction therapy. Two patients (8\%), allografted later from unrelated donors, refused HSCT after an achievement of the first CR with primary treatment. Nevertheless, they relapsed and were allografted in the second CR, 20 and 35 months since the ALL was diagnosed. The subsequent CRs were achieved in both cases with reinduction chemotherapy according to GMALL protocol used in the first-line treatment as well. All patients gave signed informed consent with the transplant procedure approved by the institutional review board.

Conditioning regimen. The conditioning regimen consisted of fludarabine ( $30 \mathrm{mg} / \mathrm{m}^{2}$ on days $-8,-7,-6,-5$ and -4$)$, melphalan $\left(70 \mathrm{mg} / \mathrm{m}^{2}\right.$ on days -3 and -2$)$ and thymoglobulin $(1.5 \mathrm{mg} / \mathrm{kg}$ on days $-4,-3,-2 \mathrm{or}$, recently, $2.0 \mathrm{mg} / \mathrm{kg}$ on days $-3,-2$ applied in 13 and 12 recipients, respectively).

HSCT. All 25 patients received donor's peripheral blood stem cells (PBSC). Stem cells from HLA-matched related donors (MRDs) and mismatched related donor (MMRD) were transplanted to 5 patients $(25 \%)$ and 1 patient $(4 \%)$, respectively. However, most HSCTs were from unrelated donors. Grafts from HLA-matched unrelated donors (MUDs) and
Table 1. Summarized data of presented study group

\begin{tabular}{|c|c|c|}
\hline & $\begin{array}{l}\text { No } \\
(\%)\end{array}$ & $\begin{array}{l}\text { median } \\
\text { (range) }\end{array}$ \\
\hline recipient' gender (female / male) & $12(48) / 13(52)$ & - \\
\hline recipient' age at diagnosis (years) & - & $34(20-58)$ \\
\hline \multicolumn{3}{|l|}{ diagnosis of ALL } \\
\hline primary & $23(92)$ & - \\
\hline secondary ${ }^{*}$ & $2(8)$ & - \\
\hline B origin & $19(76)$ & - \\
\hline T origin & $6(24)$ & - \\
\hline $\mathrm{Ph}+$ & $8(32)$ & - \\
\hline extramedullary involvement & $6(24)$ & - \\
\hline $\mathrm{WBC}>25 \times 10^{9} / \mathrm{L}$ & $4(16)$ & - \\
\hline allografting in $>1^{\text {st }}$ CR of ALL & $2(8)$ & - \\
\hline $\begin{array}{l}\text { time from diagnosis to HSCT } \\
\text { (months) }\end{array}$ & - & $6(4-35)$ \\
\hline \multicolumn{3}{|l|}{ donors } \\
\hline MRD & $5(20)$ & - \\
\hline MMRD & $1(4)$ & - \\
\hline MUD & $10(40)$ & - \\
\hline MMUD & $9(36)$ & - \\
\hline $\begin{array}{l}\text { donation from female to male } \\
\text { recipient and donor } \mathrm{ABO} / \mathrm{Rh}\end{array}$ & $2(8)$ & - \\
\hline $\begin{array}{l}\text { compatible } \\
\text { recipient and donor CMV }\end{array}$ & $7(28)$ & - \\
\hline seronegative & $4(16)$ & - \\
\hline donors' age at donation (years) & - & $31(19-51)$ \\
\hline graft - PBSC & $25(100)$ & - \\
\hline infused MNC (x 108/kg) & - & $5.98(3.94-9.85)$ \\
\hline infused CD34+ cells (x 106\% $/ \mathrm{kg})$ & - & $4.47(2.94-10.12)$ \\
\hline \multicolumn{3}{|l|}{ post-transplant GVHD prophylaxis } \\
\hline CyA & $15(60)$ & - \\
\hline CyA + MTX & $1(4)$ & - \\
\hline $\mathrm{CyA}+\mathrm{MMF}$ & $9(36)$ & - \\
\hline engraftment (assessable) & $25(100)$ & - \\
\hline ANC $\geq 0.5 \times 10^{9} / \mathrm{L}$ (+day) & - & $14(12-18)$ \\
\hline $\mathrm{PLT} \geq 20 \times 10^{9} / \mathrm{L}$ (+day) & - & $11(9-65)$ \\
\hline $100 \%$ donors' chimerism on day +30 & $22(88)$ & - \\
\hline $\begin{array}{l}\text { GVHD prophylaxis reduction and } \\
\text { withdrawal (assessable) }\end{array}$ & $21(84)$ & - \\
\hline start of CyA reduction & - & $46(28-77)$ \\
\hline stop of CyA & - & $110(92-195)$ \\
\hline acute GVHD (+day) & $4(16)$ & $28(21-32)$ \\
\hline grade II & $2(8)$ & - \\
\hline grade III & $2(8)$ & - \\
\hline chronic GVHD & $4(16)$ & - \\
\hline limited & $1(4)$ & - \\
\hline extensive & $3(12)$ & - \\
\hline CMV infection & $13(52)$ & - \\
\hline asymptomatic & $8(32)$ & - \\
\hline syndrome / disease & $5(20)$ & - \\
\hline relapse of ALL (months after HSCT) & $6(24)$ & $8(3-16)$ \\
\hline deaths (months after HSCT) & $4(16)$ & $25(12-32)$ \\
\hline post-transplant complications & $1(4)$ & - \\
\hline progression of ALL & $3(12)$ & - \\
\hline post-transplant follow-up (months) & - & $32(4-87)$ \\
\hline
\end{tabular}

* lymphoblastic crisis of CML 
mismatched unrelated donors (MMUDs) were transplanted to $10(40 \%)$ and 9 recipients (36\%), respectively. These characteristics and parameters, as well as gender of donors and recipients, their cytomegalovirus (CMV) serologic status, $\mathrm{ABO}$ and $\mathrm{Rh}$ system compatibility, the number of hematopoietic stem cells in the graft are generally summarized and fully shown in Table 1 and 2, respectively.

Post-transplant GVHD prophylaxis. As part of posttransplant GVHD prophylaxis, all patients were given cyclosporine A ( $\mathrm{CyA})$. Its intravenous administration was initiated on day -1 at a dose of $6 \mathrm{mg} / \mathrm{kg} /$ day which was subsequently adjusted so that the target plasma concentration ranged between 200 and $300 \mathrm{ng} / \mathrm{mL}$. The recipients were switched to the oral form of CyA only after manifestations of gastrointestinal RRT resolved. CyA dose reduction with a gradual decrease of its plasma concentrations was planned to be started, in the absence of any possible manifestations of GVHD or ALL relapse, between days +28 and +35 . The target was full withdrawal of CyA on days +90 to +110 . When grafts from HLA-mismatched donors were transplanted, CyA was initially combined with methotrexate (MTX) or mycophenolate mofetil (MMF) (summarized Table 1 and fully showed in Table 2). Standard "short MTX" was administered at doses of $15 \mathrm{mg} / \mathrm{m}^{2}$ on day +1 and $10 \mathrm{mg} / \mathrm{m}^{2}$ on days $+3,+6$ and +11 . The administration of MMF was initiated on day +1 at a dose of $30 \mathrm{mg} / \mathrm{kg} /$ day that was gradually reduced so that the drug was withdrawn on days +15 to +56 . As was the case of CyA, MMF was first administered intravenously and the patients were switched to the oral form only after resolution of gastrointestinal RRT.

Anti-infectious prophylaxis. Co-trimoxazole was administered at a dose of $960 \mathrm{mg}$ twice daily orally on days -8 to -1 . From day 0, it was withdrawn until the absolute neutrophil count (ANC) reached ${ }^{3} 0.5 \times 10^{9} / \mathrm{L}$. Then, co-trimoxazole was continued at the same daily dose on two days a week. Herpes virus infections were prevented by $2 \times 500 \mathrm{mg}$ of oral valacyclovir or $3 \times 250 \mathrm{mg}$ of intravenous acyclovir daily, starting from day -8 . Anti-infectious prophylaxis with both co-trimoxazole and valacyclovir or acyclovir was withdrawn 6 months after immunosuppression withdrawal and in the absence of any form of GVHD. Fluconazole at a daily dose of $200 \mathrm{mg}$ orally or intravenously was initiated on day -8 and withdrawn at the moment of a stable $\mathrm{ANC}^{3} 1.0 \times 10^{9} / \mathrm{L}$, absent GVHD and if there was no need to continue with administration of broad-spectrum antibiotics or corticosteroids. Patients with a history of confirmed or suspected systemic

Table 2. Stem cell transplantations characteristics

\begin{tabular}{|c|c|c|c|c|c|c|c|c|c|c|}
\hline $\begin{array}{l}\text { patient } \\
\text { No }\end{array}$ & $\begin{array}{l}\text { donor } \\
\text { type }\end{array}$ & $\begin{array}{c}\text { donor age } \\
\text { (years) }\end{array}$ & $\begin{array}{c}\text { gender } \\
(\mathrm{R} / \mathrm{D})\end{array}$ & $\begin{array}{c}\mathrm{ABO} / \mathrm{Rh} \\
(\mathrm{R} / \mathrm{D})\end{array}$ & $\begin{array}{c}\text { CMV serostatus } \\
(\mathrm{R} / \mathrm{D})\end{array}$ & $\begin{array}{l}\text { infused MNC } \\
\left(\times 10^{8} / \mathrm{kg}\right)\end{array}$ & $\begin{array}{c}\text { infused CD34+ } \\
\text { cells }\left(\times 10^{6} / \mathbf{k g}\right)\end{array}$ & $\begin{array}{l}\text { post-transplant } \\
\text { GVHD prophylaxis }\end{array}$ & $\begin{array}{c}\text { start of CyA } \\
\text { reduction (day) }\end{array}$ & $\begin{array}{c}\text { stop of } \\
\text { CyA (day) }\end{array}$ \\
\hline 1 & MMUD & 41 & $\mathrm{~F} / \mathrm{M}$ & $\mathrm{B}+/ \mathrm{O}+$ & $+/-$ & 6.37 & 4.46 & $\mathrm{CyA}+\mathrm{MMF}$ & +77 & +195 \\
\hline 2 & MUD & 24 & $\mathrm{M} / \mathrm{M}$ & $\mathrm{AB}+/ \mathrm{O}-$ & $+/-$ & 5.28 & 7.59 & СуA & +46 & +113 \\
\hline 3 & MUD & 35 & $\mathrm{M} / \mathrm{M}$ & $\mathrm{A}+/ \mathrm{A}-$ & $+/+$ & 6.75 & 7.0 & СуA & +50 & +110 \\
\hline 4 & MUD & 51 & $\mathrm{~F} / \mathrm{M}$ & $\mathrm{O}-/ \mathrm{O}-$ & $-/-$ & 3.94 & 5.04 & CyA & +46 & +108 \\
\hline 5 & MMUD & 29 & $\mathrm{~F} / \mathrm{M}$ & $\mathrm{O}-/ \mathrm{O}+$ & $-1+$ & 9.85 & 10.12 & $\mathrm{CyA}+\mathrm{MTX}$ & +70 & +92 \\
\hline 6 & MRD & 41 & $\mathrm{~F} / \mathrm{F}$ & $\mathrm{B}+/ \mathrm{AB}+$ & $+/+$ & 4.5 & 4.61 & СуA & +30 & +108 \\
\hline 7 & MMRD & 38 & $\mathrm{M} / \mathrm{M}$ & $\begin{array}{c}\mathrm{AB}+1 \\
\mathrm{AB}+\end{array}$ & $-/-$ & 6.48 & 3.0 & CyA + MMF & +33 & +116 \\
\hline 8 & MMUD & 43 & $\mathrm{M} / \mathrm{M}$ & $\mathrm{O}+/ \mathrm{A}+$ & $+/+$ & 5.58 & 5.05 & $\mathrm{CyA}+\mathrm{MMF}$ & +33 & +111 \\
\hline 9 & MRD & 23 & $\mathrm{M} / \mathrm{M}$ & $\mathrm{A}+/ \mathrm{O}+$ & $+/-$ & 7.56 & 5.56 & CyA & n.a & n.a. \\
\hline 10 & MMUD & 19 & $\mathrm{~F} / \mathrm{F}$ & $\mathrm{A}+/ \mathrm{A}+$ & $+/+$ & 5.28 & 4.01 & $\mathrm{CyA}+\mathrm{MMF}$ & +56 & +105 \\
\hline 11 & MRD & 27 & $\mathrm{M} / \mathrm{M}$ & $\mathrm{B}-/ \mathrm{AB}+$ & $-/-$ & 8.27 & 3.53 & CyA & n.a. & n.a. \\
\hline 12 & MMUD & 20 & $\mathrm{M} / \mathrm{F}$ & $\mathrm{B}+/ \mathrm{O}+$ & $+/+$ & 4.83 & 2.94 & CyA + MMF & +60 & +120 \\
\hline 13 & MMUD & 23 & $\mathrm{M} / \mathrm{F}$ & $\mathrm{A}+/ \mathrm{A}+$ & $+/+$ & 7.05 & 4.9 & СyA + MMF & +60 & +113 \\
\hline 14 & MMUD & 38 & $\mathrm{M} / \mathrm{M}$ & $\mathrm{A}-/ \mathrm{AB}+$ & $-/-$ & 7.82 & 5.5 & CyA + MMF & n.a & n.a. \\
\hline 15 & MMUD & 21 & $\mathrm{M} / \mathrm{M}$ & A-/A- & $+/-$ & 8.8 & 3.75 & CyA + MMF & +42 & +106 \\
\hline 16 & MRD & 42 & $\mathrm{~F} / \mathrm{F}$ & $\mathrm{A}+/ \mathrm{O}+$ & $+/+$ & 6.99 & 4.81 & СуA & n.a. & n.a. \\
\hline 17 & MUD & 22 & $\mathrm{M} / \mathrm{M}$ & $\mathrm{A}-/ \mathrm{O}+$ & $+/+$ & 4.68 & 3.75 & СуA & +30 & +125 \\
\hline 18 & MUD & 24 & $\mathrm{~F} / \mathrm{M}$ & $\mathrm{O}+/ \mathrm{O}+$ & $+/-$ & 8.08 & 4.47 & СуA & +32 & +111 \\
\hline 19 & MUD & 41 & $\mathrm{M} / \mathrm{M}$ & $\mathrm{B}+/ \mathrm{O}-$ & $+/+$ & 7.36 & 3.16 & СуA & +28 & +102 \\
\hline 20 & MMUD & 40 & $\mathrm{~F} / \mathrm{M}$ & $\mathrm{A}+/ \mathrm{O}+$ & $-1+$ & 5.25 & 4.79 & $\mathrm{CyA}+\mathrm{MMF}$ & +58 & +116 \\
\hline 21 & MUD & 26 & $\mathrm{~F} / \mathrm{M}$ & $\mathrm{AB}+/ \mathrm{A}+$ & $+/+$ & 4.62 & 4.90 & СуA & +68 & +126 \\
\hline 22 & MRD & 36 & $\mathrm{~F} / \mathrm{M}$ & $\mathrm{A}+/ \mathrm{A}+$ & $+/+$ & 5.98 & 4.20 & СуA & +58 & +106 \\
\hline 23 & MUD & 31 & $\mathrm{~F} / \mathrm{M}$ & $\mathrm{B}-/ \mathrm{O}+$ & $+/-$ & 4.24 & 3.0 & СуA & +40 & +100 \\
\hline 24 & MUD & 25 & $\mathrm{~F} / \mathrm{M}$ & $\mathrm{B}+/ \mathrm{O}+$ & $+/+$ & 5.35 & 4.47 & СуA & +42 & +103 \\
\hline 25 & MUD & 35 & $\mathrm{~F} / \mathrm{M}$ & $\mathrm{A}+/ \mathrm{O}-$ & $+/-$ & 4.75 & 3.30 & CyA & +31 & +96 \\
\hline
\end{tabular}

$\mathrm{R}$ - recipient, $\mathrm{D}$ - donor, $\mathrm{F}$ - female, $\mathrm{M}$ - male, n.a. - not applicable because of GVHD development 
fungal infection received secondary antifungal prophylaxis, namely voriconazole or posaconazole at daily doses of $200 \mathrm{mg}$ and $3 \times 200 \mathrm{mg}$ (solution) or 3x 100mg (tablets), respectively. Gastrointestinal decontamination was performed with $2 \times 400 \mathrm{mg}$ daily of rifaximin from day -8 until a stable $\mathrm{ANC}^{3}$ $0.5 \times 10^{9} / \mathrm{L}$, complete resolution of mucositis and withdrawal of broad-spectrum antibiotics. CMV-seronegative recipients transplanted from CMV-seronegative donors were substituted with leukodepleted blood products (erythrocytes and platelets). CMV-seropositive patients or CMV-seronegative ones transplanted from CMV-seropositive donors were regularly screened for the presence of CMV DNA in plasma once weekly until day +100 after HSCT, so that the risk for development of CMV disease could be eliminated by early initiation of preemptive therapy. If patients developed GVHD or were treated with corticosteroids or intensive immunosuppressive therapy, this regular monitoring was continued past day +100 .

RRT. Non-hematological RRT was assessed according to the National Cancer Institute Common Toxicity Criteria, version 2.0 [11].

Hematopoietic recovery, engraftment and therapeutic respons. Post-transplant hematopoietic recovery was defined as the first of three subsequent days with a stable $\mathrm{ANC}^{3} 0.5 \times 10^{9} / \mathrm{L}$ and platelets (PLTs) count ${ }^{3} 20 \times 10^{9} / \mathrm{L}$ in recipients' peripheral blood. Cellular chimerism was assessed in peripheral blood nucleated cells and bone marrow aspirate on days $+15,+60,+270$ and $+30,+90,+180,+360$, respectively, using amplification of microsatellite DNA short tandem repeats (STR) with fluorescently labeled primers in polymerase chain reaction and subsequent separation by capillary electrophoresis. Prior to HSCT, blood samples were collected from both recipients and donors and their STR profiles were determined. Those were used in the post-transplant period to quantify donor's chimerism [12]. Complete donor's chimerism was defined as $100 \%$ of donor's nucleated cells in peripheral blood or bone marrow. Post-transplant relapse of ALL was confirmed if following criteria had been fulfilled: $>5 \%$ of original recipient's pathological lymphoblasts in bone marrow (with or without their finding in peripheral blood, decreased hemoglobin level, ANC and PLTs) and/ or proven extramedullary involvement (e.g. leukemic cells in cerebrospinal fluid or proven pathological lymphoblastic infiltration of any tissue).

GVHD diagnosis and assessment. Acute or chronic GVHD was diagnosed based on the clinical features, laboratory findings and histological results from biopsy samples of the affected tissue. Acute GVHD stages and grades were determined in accordance with standard criteria [13]. When assessing chronic GVHD, the original classification into limited and extensive forms was used based on the extent and intensity [14].

Statistical analysis. The Kaplan-Meier method was used to calculate EFS and OS. EFS was defined as the interval from HSCT to relapse of the disease or death from any cause. OS was defined as the interval from HSCT to the death from any cause. The analysis was carried out using the SPSS, version 15 software (SPSS Inc., Chicago, USA).

\section{Results}

Mucositis (stomatitis and/or gastrointestinal involvement) as the dominant manifestation of non-hematologic RRT was observed in 18 patients ( $72 \%)$; in only 5 cases (20\%), however, grade III was noted (data not shown). Renal and liver RRT, developed in $9(36 \%)$ and 2 recipients (8\%), respectively. Nevertheless, only one patient (4\%) suffered from the renal RRT grade III and liver involvement did not exceed grade I (data not shown). Post-transplant thrombotic microangiopathy (TMA) grade II developed in one recipient (4\%) allografted in the second CR of ALL and completely resolved with the change of GVHD prophylaxis (CyA was switched to the combination of MMF with corticosteroids that was gradually reduced and stopped according to mentioned plan on day +102$)$ and the treatment of confirmed human herpesvirus type 6 (HHV6) reactivation with virostatics.

Successful engraftment was achieved in all patients. Stable ANC $\geq 0.5 \times 10^{9} / \mathrm{L}$ and PLT $\geq 20 \times 10^{9} / \mathrm{L}$ were achieved at a median of 14 (range, 12-18) and 11 (range, 9-65) days after HSCT. Complete donor's chimerism on day +30 was detected in 22 recipients (88\%) (summarized in Table 1 and fully showed in Table 3).

In 21 assessable patients (84\%), dose reduction and full withdrawal of CyA were within a median of 46 (range, 28-77) and 110 (range, 92-195) days after HSCT, respectively (summarized Table 1 and fully showed in Table 2). The delays were associated with the findings that could have been linked to the development of GVHD in $14(56 \%)$ and 10 patients (40\%), respectively. However, the complication was not confirmed by the subsequent clinical course and examination results including the histology of involved tissue. The delays of reduction and withdrawal of $\mathrm{CyA}$ in these recipients, comparing to proposed protocol, were in the median of 24 (range, 5-42) and 6 (range, 1-85) days, respectively. In four cases (16\%), the early reduction and withdrawal of prophylactic immunosuppression were not carried out according to protocol due to development of acute GVHD.

The grade II and III of acute GVHD were equally observed in two (8\%) of these four patients, respectively. The first clinical symptoms and/or laboratory findings of acute GVHD developed in the median of 28 (range, 21-32) post-transplant days. In presented group of 25 patients and the post-transplant follow-up median of 32 (range, 4-87) months, after HSCT with the above conditioning regimen and GVHD prophylaxis, chronic GVHD developed in four cases (16\%). A limited and extensive form were observed in $1(4 \%)$ and $3(12 \%)$ recipients, respectively. One of them with extensive chronic GVHD died of septic shock 12 months after HSCT (summarized Table 1 and fully showed in Table 3).

Primary or reactivated CMV infections were observed in $1(4 \%)$ and $12(48 \%)$ patients, respectively. It was clinically 
Table 3 Patients' post-transplant outcome

\begin{tabular}{|c|c|c|c|c|c|c|c|c|c|}
\hline \multirow[b]{2}{*}{$\begin{array}{l}\text { patient } \\
\text { No }\end{array}$} & \multicolumn{3}{|c|}{ engraftment } & \multirow[b]{2}{*}{$\begin{array}{c}\text { acute GVHD } \\
\text { (day, grade) }\end{array}$} & \multirow[b]{2}{*}{$\begin{array}{c}\text { chronic GVHD } \\
\text { (severity) }\end{array}$} & \multirow[b]{2}{*}{ CMV reactivation } & \multirow[b]{2}{*}{$\begin{array}{c}\text { post-transplant } \\
\text { ALL relapse } \\
\text { (months) }\end{array}$} & \multirow[b]{2}{*}{$\begin{array}{l}\text { death } \\
\text { (cause) }\end{array}$} & \multirow[b]{2}{*}{$\begin{array}{c}\text { post-transplant } \\
\text { follow-up } \\
\text { (months) }\end{array}$} \\
\hline & $\begin{array}{c}\mathrm{ANC} \geq \\
0.5 \times 10^{9} / \mathrm{L} \\
(\text { day })\end{array}$ & $\begin{array}{c}\text { PLT } \geq \\
20 \times 10^{9} / \mathrm{L} \\
(\text { day })\end{array}$ & $\begin{array}{c}\text { donor's } \\
\text { chimerism } \\
\text { on day }+30\end{array}$ & & & & & & \\
\hline 1 & +13 & +11 & $97 \%$ & no & no & yes (syndrome) & no & no & 65 \\
\hline 2 & +14 & +9 & $100 \%$ & no & no & yes (asymptomatic) & no & no & 65 \\
\hline 3 & +15 & +10 & $100 \%$ & no & no & no & no & no & 46 \\
\hline 4 & +12 & +12 & $100 \%$ & no & no & no & no & no & 38 \\
\hline 5 & +17 & +12 & $100 \%$ & no & no & yes (asymptomatic) & yes (3) & no & 35 \\
\hline 6 & +17 & +13 & $100 \%$ & no & no & no & yes (16) & yes (PD) & 32 \\
\hline 7 & +16 & +13 & $100 \%$ & no & no & no & no & no & 23 \\
\hline 8 & +15 & +10 & $100 \%$ & no & no & yes (asymptomatic) & no & no & 17 \\
\hline 9 & +14 & +10 & $100 \%$ & yes $(+30, \mathrm{II})^{*}$ & no & yes $^{*}$ & no & no & 14 \\
\hline 10 & +16 & +12 & $100 \%$ & no & no & yes (asymptomatic) & no & no & 13 \\
\hline 11 & +15 & +11 & $100 \%$ & yes $(+26, \mathrm{III})$ & no & no & no & no & 11 \\
\hline 12 & +14 & +11 & $100 \%$ & no & no & no & no & no & 10 \\
\hline 13 & +13 & +11 & $100 \%$ & no & no & no & no & no & 12 \\
\hline 14 & +14 & +11 & $100 \%$ & yes $(+32, \mathrm{II})$ & yes (extensive) & no & no & yes (sepsis) & 12 \\
\hline 15 & +12 & +14 & $100 \%$ & no & no & no & yes (8) & yes (PD) & 18 \\
\hline 16 & +13 & +10 & $100 \%$ & yes $(+21, \mathrm{III})$ & yes (extensive) & yes (asymptomatic) & no & no & 28 \\
\hline 17 & +13 & +10 & $100 \%$ & no & no & yes (syndrome) & no & no & 27 \\
\hline 18 & +12 & +12 & $100 \%$ & no & yes (limited) & yes (asymptomatic) & yes (9) & yes (PD) & 14 \\
\hline 19 & +12 & +65 & $100 \%$ & no & no & no & no & no & 21 \\
\hline 20 & +16 & +12 & $100 \%$ & no & no & no & no & no & 22 \\
\hline 21 & +13 & +10 & $98 \%$ & no & yes (extensive) & yes (asymptomatic) & no & no & 21 \\
\hline 22 & +13 & +10 & $100 \%$ & no & no & no & yes (12) & no & 14 \\
\hline 23 & +18 & +11 & $100 \%$ & no & no & yes (syndrome) & no & no & 11 \\
\hline 24 & +12 & +9 & $100 \%$ & no & no & yes (syndrome) & yes (7) & no & 8 \\
\hline 25 & +13 & +10 & $99 \%$ & no & no & yes (asymptomatic) & no & no & 4 \\
\hline
\end{tabular}

$\mathrm{PD}$ - progression of primary disease, ${ }^{\star}$ histological confirmation of acute GVHD and concomitant detection of CMV DNA in gut mucosa

manifested in 5 recipients (20\%). In 4 cases (16\%), CMV syndrome developed. In one patient, CMV DNA was detected in both plasma and intestinal mucosa obtained by biopsy and the clinical manifestation of the infection (i.e. either CMV syndrome or gastrointestinal CMV disease) could not be reliably determined due to histologically confirmed concomitant acute GVHD (summarized Table 1 and fully showed in Table 3). Following virostatic therapy, the symptoms disappeared completely in the former patients. The latter patient's condition also improved but it was more difficult to assess due to the parallel immunosuppressive therapy for acute GVHD.

In 6 ALL cases (24\%), the underlying disease relapsed at the median of 8 (range, 3-16) months after HSCT (Table 3). Three (12\%) cases (patients No.6, No.15 and No.18) were isolated extramedullary relapses (two with CNS involvement and one with an infiltration of soft tissues and bones arround the right hip joint) without the diffuse bone marrow involvement. One (4\%) recipient (patient No.5) developed systemic relapse of ALL with bone marrow as well as CNS involvement. The bone marrow relapse without any evidence of extramedullary involvement were observed in the rest two (8\%) patients (patients No.22 and No.24). Significantly delayed start of CyA reduction was noted in two (33.3\%) relapsed recipients (on days +58 and +70 ). However, there was almost no delay in the withdrawal of immunosuppression comparing to protocol (range, 92-111 post-transplant days). One relapsed patient (16.7\%) was allografted in the second CR of ALL, other three ones $(50 \%)$ had poor prognostic cytogenetic findings, $t(9 ; 22)$ (q34; 11$)$ and $\mathrm{t}(4 ; 11)(\mathrm{q} 21 ; \mathrm{q} 23)$ in one $(16.7 \%)$ and two cases (33.3\%), respectively. All but one relapsed patients were without the evidence of any GVHD form. Only one developed limited chronic GVHD without the need of any systemic immunosuppressive treatment.

Five of relapsed patients $(83.3 \%)$ achieved another CR after the second transplantation with cryopreserved hematopoietic cells obtained from the original donors. Intravenous high-dose $\operatorname{MTX}\left(3 \mathrm{~g} / \mathrm{m}^{2}\right)$ and intrathecal treatment (MTX $15 \mathrm{mg}$, cytarabine $40 \mathrm{mg}$, dexamethason $4 \mathrm{mg}$ ) were used in three recipients to reduce CNS leukemic involvement at relapse. All five patients were allografted after non-myeloablative conditioning regimen FLAG-Ida (fludarabine $120 \mathrm{mg} / \mathrm{m}^{2}$, cytarabine $8 \mathrm{~g} /$ $\mathrm{m}^{2}$, idarubicin $36 \mathrm{mg} / \mathrm{m}^{2}$ ) and CyA was the only immunosup- 
pressant in GVHD prophylaxis, regardless of recipient/donor HLA compatibility. Moreover, to enhance GVL effect, CyA was tapered since day +14 and withdrawn on day +42 . Two patients with isolated CNS involvement relapsed again in the same location and died 41 and 18 months after the first HSCT, respectively. The sixth patient was commended to palliative treatment and died of disease progression 14 months after allografting. The last three subsequently allografted recipients have survived 57, 14 and 8 months after the first transplantation, respectively. One of these patients developed extensive chronic GVHD that regressed with combined immunosuppressive therapy; at 53 months after the second HSCT, she still remains in CR of ALL. The other two patients have also achieved the CR but their actual post-transplant follow-up is too short, equally 2 months in both cases.

At a median post-transplant follow-up of 32 (range, 4-87) months, NRM and overall mortality in the group were $4 \%$ and $16 \%$, respectively. The probabilities of 2-year EFS and OS were 70.3\% (95\% CI 51.9-88.7\%) and 86.1\% (95\% CI 71.6-100\%), respectively (Figure 1).

\section{Discussion}

Some recent studies proved no significant differences in general outcome between the patients with ALL allografted after myeloablative conditioning (MAC) and RIC [15]. Our updated results confirmed an efficacy of allogeneic HSCT following RIC in adult patients with high-risk ALL (including lymphoblastic crises of CML) in the CR. Nevertheless, several proposals had played an integral role in the design of reported transplant approach.

RIC contained fludarabine and melphalan has been associated with acceptable RRT. Mucositis and gastrointestinal involvement represented the major features of organ toxicity. However, gastrointestinal RRT did usually not overcome grade II/III $[6,7]$ as also observed in our previous [5] and recent study. Other forms of RRT were mild and less frequent. In spite of relatively low general non-hematological toxicity, reduced combination of fludarabine and "high-dose" melphalan had significant myelosuppressive and immunosuppressive potential that allowed to achieve a stable engraftment of donor hematopoietic and immunocompetent cells responsible for GVL effect $[7,16]$.

On the other hand, regardless of the grade, mucositis as the major form of RRT and early engraftment after RIC combined fludarabine with melphalan may trigger some immunopathophysiological mechanisms responsible for GVHD development $[17,18]$. Therefore we decided to include "in vivo" T-depletion with thymoglobulin as a part of conditioning regimen to suppress the early activation of immunopathophysiological cascade resulted in GVHD clinical manifestation. And indeed, acute GVHD was observed and histologically confirmed in 4 recipients (16\%) only. These results support an efficacy of "in vivo" T-depletion to prevent early post-transplant serious immunological complications.

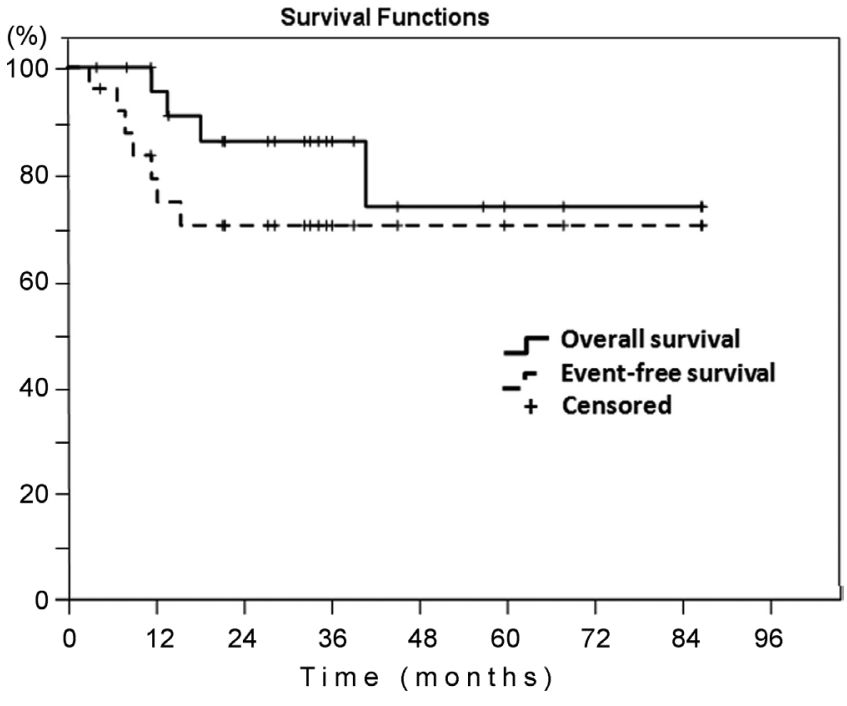

Figure 1. Estimated event-free and overall survival Kaplan-Meier's curves of presented cohort

There might be also some arguments against the use of ATG, particularly in the cases allografted from HLA-mathed donors, because of the possible suppression of required GVL reaction. Therefore the integral parts of treatment strategy remained early reduction and withdrawal of post-transplant immunosuppressive GVHD prophylaxis as previously established in our pilot study [5]. Despite some delays of CyA reduction and withdrawal in $14(56 \%)$ and $10(40 \%)$ of assessable patients, respectively, the administration of post-transplant prophylactic immunosuppression was still significantly shorter than in published studies $[19,20]$. Nevertheless, after the first transplantation, chronic GVHD and its extensive form developed only in $4(16 \%)$ and $3(12 \%)$ patients, respectively. Earlier initiation of reduction and withdrawal of GVHD prophylaxis was also reported by Cho et al. in patients with high-risk ALL transplanted in the first or second CR after RIC combining fludarabine and melphalan (FM) [21]. The 3-year diseasefree survival (DFS) and OS rates were $62.6 \%$ and $64.1 \%$, respectively. However, the apparent antileukemic effectiveness was accompanied by higher rates of both GVHD and NRM. Thymoglobulin was administered less frequent (only in 6 recipients transplanted from MMUDs) and in lower total doses $(2.5 \mathrm{mg} / \mathrm{kg})$. Similar results were reported by Stein et al. in ALL patients transplanted from MRDs or MUDs after the same FM regimen [22]. "In vivo" T-cell depletion was performed in only one patient. GVHD was prevented by administration of tacrolimus and sirolimus or CyA and MMF; in 14 patients, MTX was added to these combinations. The time schedule of reduction and complete withdrawal of calcineurin inhibitors was not stated. The probability of 2-year DFS and OS was $61.5 \%$. However, the development of acute and chronic GVHD was observed in $75 \%$ and $86 \%$ of patients, respectively, with 2 -year NRM of $21.5 \%$. On the other hand, there was observed 
just one death (4\%) caused by post-transplant complications in our cohort during presented follow-up period.

This study presents updated results of specific approach to the allografting in adult patients with probably otherwise incurable lymphoblastic neoplasias. "In vivo" T-cell depletion with thymoglobulin as a standard part of RIC was confirmed to influence the occurrence of GVHD and NRM regardless of relatively high proportion of patients transplanted from HLAmismatched donors (40\%). Early reduction and withdrawal of post-transplant GVHD prophylaxis did not lead to the increase of serious immunological complications. However, despite the high-risk primary disease, antileukemic control with GVL reaction has been apparent in most treated patients.

Supplementary information is available in the online version of the paper.

Acknowledgements: This work was supported by the grant MSM 6198959205 from the Czech Ministry of Education and the project IGA-LF-2016-001 of Palacky University in Olomouc.

\section{References}

[1] HUNAULT M, HAROUSSEAU JL, DELAIN M, TRUCHANGRACZYK M, CAHN JY et al. Better outcome of adult acute lymphoblastic leukemia after early genoidentical allogeneic bone marrow transplantation (BMT) than after late high-dose therapy and autologous BMT: a GOELAMS trial. Blood 2004; 104: 3028-3037. https://doi.org/10.1182/blood-2003-10-3560

[2] GOLDSTONE AH, RICHARDS SM, LAZARUS HM, TALLMAN MS, BUCK G et al. In adults with standard-risk acute lymphoblastic leukemia, the greatest benefit is achieved from a matched sibling allogeneic transplantation in first complete remission, and an autologous transplantation is less effective than conventional consolidation/maintenance chemotherapy in all patients: final results of the International ALL Trial (MRC UKALL XII/ECOG E2993). Blood 2008; 111: 1827-1833. https://doi.org/10.1182/blood-2007-10-116582

[3] MARKS DI, PEREZ WS, HE W, ZHANG MJ, BISHOP MR et al. Unrelated donor transplants in adults with Philadelphianegative acute lymphoblastic leukemia in first complete remission. Blood 2008; 112: 426-434. https://doi.org/10.1182/ blood-2007-12-128918

[4] MOHTY M, LABOPIN M, VOLIN L, GRATWOHL A, SOCIE G et al. Reduced-intensity versus conventional myeloablative conditioning allogeneic stem cell transplantation for patients with acute lymphoblastic leukemia: a retrospective study from the European Group for Blood and Marrow Transplantation. Blood 2010; 116 : 4439-4443. https://doi.org/10.1182/blood-2010-02-266551

[5] RAIDA L, RUSINAKOVA Z, SZOTKOWSKA R, KUBA A, FABER E et al. Allogeneic stem cell transplantation after fludarabine, melphalan and thymoglobulin followed by early withdrawal of prophylactic immunosuppression could be an effective approach to patients with acute lymphoblastic leukemia. Neoplasma 2015; 62: 805-811. d https://doi.org/10.4149/ neo $2015 \quad 097$
[6] DASGUPTA RK, RULE S, JOHNSON P, DAVIES J, BURNETT A et al. Fludarabine phosphate and melphalan: a reduced intensity conditioning regimen suitable for allogeneic transplantation that maintains the graft versus malignancy effect. Bone Marrow Transplant 2006; 37: 455-461. https://doi.org/10.1038/sj.bmt.1705271

[7] RITCHIE DS, MORTON J, SZER J, ROBERTS AW, DURRANT S et al. Graft-versus-host disease, donor chimerism, and organ toxicity in stem cell transplantation after conditioning with fludarabine and melphalan. Biol Blood Marrow Transplant 2003; 9: 435-442.

[8] VAN BESIEN K, KUNAVAKKAM R, RONDON G, DE LIMA M, ARTZ A et al. Fludarabine-Melphalan Conditioning for AML and MDS: Alemtuzumab Reduces Acute and Chronic GVHD without Affecting Long-Term Outcomes. Biol Blood Marrow Transplant 2009; 15: 610-617. https://doi. org/10.1016/j.bbmt.2009.01.021

[9] LARSON RA, DODGE RK, BURNS CP, LEE EJ, STONE $\mathrm{RM}$ et al. A Five-Drug Remission Induction Regimen With Intensive Consolidation for Adults With Acute Lymphoblastic Leukemia: Cancer and Leukemia Group B Study 8811. Blood 1995; 85: 2025-2037.

[10] FOLBER F, SALEK C, DOUBEK M, SOUKUPOVA MAALOUFOVA J, VALOVA $\mathrm{T}$ et al. Treatment of adult acute lymphoblastic leukemia according to GMALL 07/2003 study protocol in the Czech Republic - the first experience. Vnitr Lek 2010; 56: 176-182.

[11] TROTTI A, BYHARDT R, STETZ J, GWEDE C, CORN B et al. Common toxicity criteria: version 2.0. an improved reference for grading the acute effects of cancer treatment: impact on radiotherapy. Int J Radiat Oncol Biol Phys 2000; 47: 13-47.

[12] NOLLET F, BILLIET J, SELLESLAG D, CRIEL A. Standardisation of multiplex fluorescent short tandem repeat analysis for chimerism testing. Bone Marrow Transplant 2001; 28: 511-518. https://doi.org/10.1038/sj.bmt.1703162

[13] PRZEPIORKA D, WEISDORF D, MARTIN P, KLINGEMANN HG, BEATTY P et al. 1994 Consensus Conference on Acute GVHD Grading. Bone Marrow Transplant 1995; 15: 825-828.

[14] SULLIVAN KM, AGURA E, ANASETTI C, APPELBAUM F, BADGER C et al. Chronic graft-versus-host disease and other late complications of bone marrow transplantation. Semin Hematol 1991; 28: 250-259.

[15] EOM KS, SHIN SH, YOON JH, YAHNG SA, LEE SE et al. Comparable long-term outcomes after reduced-intensity conditioning versus myeloablative conditioning allogeneic stem cell transplantation for adult high-risk acute lymphoblastic leukemia in complete remission. Am J Hematol 2013; 88: 634-641. https://doi.org/10.1002/ajh.23465

[16] MEDD PG, PENIKET AJ, LITTLEWOOD TJ, PEARCE R, PERRY J et al. Evidence for a GVL effect following reducedintensity allo-SCT in ALL: a British Society of Blood and Marrow Transplantation study. Bone Marrow Transplant 2013; 48: 982-987. https://doi.org/10.1038/bmt.2012.261

[17] LIU D, YAN C, XU L, WANG Y, HAN W et al. Diarrhea during the conditioning regimen is correlated with the oc- 
currence of severe acute graft-versus-host disease through systemic release of inflammatory cytokines. Biol Blood Marrow Transplant 2010; 16: 1567-1575. https://doi.org/10.1016/j. bbmt.2010.05.001

[18] GOLDBERG J, JACOBSOHN DA, ZAHURAK ML, VOGELSANG GB. Gastrointestinal toxicity from the preparative regimen is associated with an increased risk of graft-versushost disease. Biol Blood Marrow Transplant 2005; 11: 101-107. https://doi.org/10.1016/j.bbmt.2004.10.007

[19] MOHTY M, BAY JO, FAUCHER C, CHOUFI B, BILGER K et al. Graft-versus-host disease following allogeneic transplantation from HLA-identical sibling with antithymocyte globulin-based reduced-intensity preparative regimen. Blood 2003; 102: 470-476. https://doi.org/10.1182/blood-2002-12-3629

[20] BACHANOVA V, VERNERIS MR, DEFOR T, BRUNSTEIN CG, WEISDORF D. Prolonged survival in adults with acute lymphoblastic leukemia after reduced-intensity conditioning with cord blood or sibling donor transplantation. Blood 2009; 113: 2902-2905. https://doi.org/10.1182/ blood-2008-10-184093

[21] CHO BS, LEE S, KIM YJ, CHUNG NG, EOM KS et al. Reduced-intensity conditioning allogeneic stem cell transplantation is a potential therapeutic approach for adults with high-risk acute lymphoblastic leukemia in remission: results of a prospective phase 2 study. Leukemia 2009; 23: 1763-1770. https://doi.org/10.1038/leu.2009.102

[22] STEIN AS, PALMER JM, O'DONNELL MR, KOGUT NM, SPIELBERGER RT et al. Reduced-Intensity Conditioning followed by Peripheral Blood Stem Cell Transplantation for Adult Patients with High-Risk Acute Lymphoblastic Leukemia. Biol Blood Marrow Transpl 2009; 15: 1407-1414. https:// doi.org/10.1016/j.bbmt.2009.07.003 
Suppl Table 1 Patients' characteristics of primary disease and pre-transplant treatment

\begin{tabular}{|c|c|c|c|c|c|c|c|c|}
\hline $\begin{array}{c}\text { patient } \\
\text { No }\end{array}$ & gender & $\begin{array}{l}\text { age at } \\
\text { diagnosis } \\
\text { (years) }\end{array}$ & $\begin{array}{l}\text { type } \\
\text { of } \\
\text { ALL }\end{array}$ & cytogenetic findings at diagnosis* & $\begin{array}{l}\text { WBC } \\
\text { at diagnosis } \\
(\mathbf{x 1 0} / \mathbf{L})\end{array}$ & $\begin{array}{l}\text { extramedullary } \\
\text { involvement } \\
\text { at diagnosis }\end{array}$ & $\begin{array}{l}\text { primary } \\
\text { therapeutic } \\
\text { protocol }\end{array}$ & $\begin{array}{l}\text { time from } \\
\text { diagnosis } \\
\text { to HSCT } \\
\text { (months) }\end{array}$ \\
\hline 1 & female & 24 & common B & $46, X X, t(12 ; 22)(p ? 12 ; q ? 13)$ & 8.5 & none & CALGB & 6 \\
\hline 2 & male & 50 & common B & $\begin{array}{c}\text { standard cytogenetic methods failed, } \\
\text { BCR-ABL1fusion with breakpoint in minor region was confirmed } \\
\text { by the method of molecular genetics }\end{array}$ & 2.4 & none & $\begin{array}{c}\text { CALGB } \\
+ \text { imatinib }\end{array}$ & 5 \\
\hline 3 & male & 57 & common B & $52, \mathrm{XY},+\mathrm{X},+10, \operatorname{der}(14) \mathrm{t}(8 ; 14)(\mathrm{q} ? 12 ; \mathrm{q} 32.3),+17,+20,+21,+21$ & 5.37 & none & CALGB & 5 \\
\hline 4 & female & 34 & pre-B & $46, \mathrm{XX}, \operatorname{der}(20) \mathrm{t}(1 ; 20)(\mathrm{q} ? 21 ; ?)$ & 2.39 & none & GMALL & 7 \\
\hline 5 & female & 25 & pre-B & 46,XX,t(X;6)(p?21;p?23),del(9)(p21) & 34.3 & none & GMALL & 6 \\
\hline 6 & female & 34 & pre-B & $\begin{array}{c}47, \mathrm{XX}, \mathrm{t}(4 ; 11)(\mathrm{q} 21 ; \mathrm{q} 23),+\operatorname{der}(4) \mathrm{t}(4 ; 11)(\mathrm{q} 21 ; \mathrm{q} 23) / \\
48, \mathrm{XX},+\operatorname{der}(\mathrm{X}) ? \operatorname{del}(\mathrm{X})(\mathrm{q} ? 24), \mathrm{t}(4 ; 11)(\mathrm{q} 21 ; \mathrm{q} 23) \\
+\operatorname{der}(4) \mathrm{t}(4 ; 11)(\mathrm{q} 21 ; \mathrm{q} 23)\end{array}$ & 14.19 & none & GMALL & 4 \\
\hline 7 & male & 39 & common B & $46, \mathrm{XY}$ & 5.92 & CNS & GMALL & 5 \\
\hline 8 & male & 28 & pre-T & $46, X Y$ & 10.76 & $\begin{array}{l}\text { retroperitoneal } \\
\text { lymph nodes } * * *\end{array}$ & GMALL & 5 \\
\hline 9 & male & 25 & medullary $\mathrm{T}$ & 46,XY,del(9)(p21)3/47,XY,+6,del(9)(p21) & 11.95 & pericardium $* * *$ & GMALL & 6 \\
\hline 10 & female & 25 & pre-T & $47, \mathrm{XX},+4$ & 1.23 & none & GMALL & 6 \\
\hline 11 & male & 25 & common B & $\begin{array}{c}69, \mathrm{XY},+\mathrm{X},+\mathrm{Y},+2,+4,+5,+5,+6,+8, \mathrm{t}(9 ; 22)(\mathrm{q} 34 ; \mathrm{q} 11.2),+10,+10, \\
+11,+13,+14,+14,+15,+16,+17,+18,+19,+20,+20,+21,+\operatorname{der}(22) \\
\mathrm{t}(9 ; 22)(\mathrm{q} 34 ; \mathrm{q} 11.2)\end{array}$ & 5.42 & none & $\begin{array}{c}\text { GMALL } \\
+ \text { imatinib }\end{array}$ & 6 \\
\hline 12 & male & 42 & common B & $\begin{array}{c}48, X,-Y,+X,+2,+6,-7,-9, \mathrm{t}(9 ; 22)(\mathrm{q} 34 ; \mathrm{q} 11.2),+14,+\operatorname{der}(22) \\
\mathrm{t}(9 ; 22)(\mathrm{q} 34 ; \mathrm{q} 11.2) / \\
49, \mathrm{X},-\mathrm{Y},+\mathrm{X},+2,+6,-7,-9, \mathrm{t}(9 ; 22)(\mathrm{q} 34 ; \mathrm{q} 11.2),+14,+14,+\operatorname{der}(22) \\
\mathrm{t}(9 ; 22)(\mathrm{q} 34 ; \mathrm{q} 11.2)\end{array}$ & 22.6 & none & $\begin{array}{c}\text { GMALL } \\
+ \text { imatinib }\end{array}$ & 7 \\
\hline 13 & male & 40 & common $\mathrm{B} * *$ & $\begin{array}{c}\text { 51,XY,+Y,+2,+5,+6,-7, t(9;22)(q34;q11) } \\
\operatorname{inv}(9)(\mathrm{p} 13 ; \mathrm{q} 34.3),+10,+\operatorname{der}(22) \mathrm{t}(9 ; 22)(\mathrm{q} 34 ; \mathrm{q} 11)\end{array}$ & 15.63 & none & $\begin{array}{c}\text { GMALL } \\
\text { + dasatinib }\end{array}$ & 5 \\
\hline 14 & male & 54 & common $\mathrm{B} * *$ & $46, X Y, t(9 ; 22)(\mathrm{q} 34 ; \mathrm{q} 11)$ & 38.22 & none & $\begin{array}{l}\text { CALGB } \\
+ \text { imatinib }\end{array}$ & 8 \\
\hline 15 & male & 22 & pre-B & 46,XY,?del(2)(q?),ins(16;2)(q?12;q?) & 3.5 & CNS & GMALL & 20 \\
\hline 16 & female & 43 & pre-B & $46, \mathrm{XX}$ & 1.7 & none & GMALL & 5 \\
\hline 17 & male & 46 & common B & $46, X Y, t(9 ; 22)(q 34 ; q 11.2) / 47, X Y,+21$ & 2.05 & none & $\begin{array}{c}\text { GMALL } \\
+ \text { imatinib }\end{array}$ & 6 \\
\hline 18 & female & 53 & pre-B & $60-63, \mathrm{XXX}, ?+1,-3,-4,-5,-11,-12,-13,-16,-17,-18,+21,+1-2 \mathrm{mar}$ & 17.19 & none & GMALL & 5 \\
\hline
\end{tabular}




\begin{tabular}{|c|c|c|c|c|c|c|c|c|}
\hline 19 & male & 22 & pre-T & $46, X Y, \operatorname{del}(9)(\mathrm{p} 21)$ & 10.59 & $\mathrm{CNS}$ & GMALL & 35 \\
\hline 20 & female & 29 & pre-T & $46, X X$ & 18.58 & pericardium $* * *$ & GMALL & 6 \\
\hline 21 & female & 27 & pre-T & $46, \mathrm{XX}$ & 1.79 & none & GMALL & 5 \\
\hline 22 & female & 35 & common B & $\begin{array}{c}47, \mathrm{XX}, \mathrm{t}(9 ; 22)(\mathrm{q} 34 ; \mathrm{q} 11), \operatorname{del}(9)(\mathrm{p} 21),+\operatorname{der}(22) \mathrm{t}(9 ; 22)(\mathrm{q} 34 \mathrm{q} 11) / \\
46, \mathrm{XX}, \mathrm{t}(9 ; 22)(\mathrm{q} 34 ; \mathrm{q} 11), \operatorname{del}(9)(\mathrm{p} 21)\end{array}$ & 6.71 & none & $\begin{array}{l}\text { CALGB } \\
+ \text { imatinib } \\
\end{array}$ & 5 \\
\hline 23 & female & 58 & pre-B & $\begin{array}{c}\text { 47,XX,der(1)t(1;18)(p?33;q?16)t(6;18)(q?21;?p?),der(4)t(4;15) } \\
(\mathrm{p} ? 6 ; ? \mathrm{q} ?), \operatorname{der}(6) \mathrm{t}(6 ; 8)(\mathrm{q} ? 15 ; ? \mathrm{p} ?),+\operatorname{der}(10), \operatorname{del}(10)(\mathrm{q} ? 22 ; \mathrm{qter}) \\
\operatorname{der}(18) \mathrm{t}(1 ; 18)(? \mathrm{q} ? ; \mathrm{p} ? 11) / 47, \mathrm{XX}, \operatorname{der}(1) \mathrm{t}(1 ; 18)(\mathrm{p} ? 33 ; \mathrm{q} ? 16) \mathrm{t}(6 ; 18) \\
(\mathrm{q} ? 21 ; ? \mathrm{p} ?), \operatorname{der}(4) \mathrm{t}(4 ; 15)(\mathrm{p} ? 16 ; ? \mathrm{q} ?), \operatorname{der}(6) \mathrm{t}(6 ; 8)(\mathrm{q} ? 15 ; ? \mathrm{p} ?),+10 \\
\operatorname{der}(18) \mathrm{t}(1 ; 18)(? \mathrm{q} ; \mathrm{p} ? 11)\end{array}$ & 1.91 & none & GMALL & 6 \\
\hline 24 & female & 34 & pre-B & $\begin{array}{c}\text { 47,XX,?del(X)(q?23),+X,t(4;11)(q21;q23),der(9)(del(9)(p21) } \\
\operatorname{del}(9)(\mathrm{q} 22) / 46, X X, \mathrm{t}(4 ; 11)(\mathrm{q} 21 ; \mathrm{q} 23), \operatorname{der}(9)(\operatorname{del}(9)(\mathrm{p} 21) \operatorname{del}(9)(\mathrm{q} 22)\end{array}$ & 51.45 & none & GMALL & 4 \\
\hline 25 & female & 52 & common B & $\begin{array}{c}50, \mathrm{XX},+2,+5, \operatorname{del}(9)(\mathrm{p} 21), \mathrm{t}(9 ; 22)(\mathrm{q} 34 ; \mathrm{q} 11),+10,+21 / 50, \mathrm{XX},+2 \\
\mathrm{t}(5 ; 9)(\mathrm{q} ? 34 ; \mathrm{p} ? 12), \mathrm{t}(9 ; 22)(\mathrm{q} 34 ; \mathrm{q} 11), \operatorname{der}(9) \operatorname{del}(9)(\mathrm{p} 21),+5,+10,+21 / \\
46, \mathrm{XX}, \mathrm{t}(9 ; 22)(\mathrm{q} 34 ; \mathrm{q} 11)\end{array}$ & 61.21 & none & $\begin{array}{l}\text { GMALL } \\
+ \text { imatinib }\end{array}$ & 6 \\
\hline
\end{tabular}

* evaluated by the methods of classic cytogenetics and fluorescence in situ hybridization (FISH)

** lymphoblastic crisis of CML

*** manifestation of mediastinal mass at diagnosis 